\title{
The Translation of Adverbial Beta Clause Functions by Using Google Translate
}

\author{
Muhammed Ibrahim Hamood ${ }^{1} \&$ Mahmood Abdul Khaliq Al-Bagoa ${ }^{2}$ \\ ${ }^{1}$ College of Arts, University of Mosul, Mosul City, Iraq \\ ${ }^{2}$ Education College for Girls, University of Mosul, Mosul City, Iraq \\ Correspondence: Dr. Muhammed Ibrahim Hamood, College of Arts, University of Mosul, Mosul City, Iraq. \\ E-mail: dr-mihamood@uomosul.edu.iq
}

\author{
Received: October 28, $2020 \quad$ Accepted: January 30, $2021 \quad$ Online Published: February 9, 2021 \\ doi:10.5539/ijel.v11n2p118 URL: https://doi.org/10.5539/ijel.v11n2p118
}

\begin{abstract}
This study focuses on the translation of the English adverbial clause from English into Arabic. The first main purpose of this research is to investigate how the English adverbial beta clause functions are rendered into the Arabic texts by using "Google Translate". The second objective is to preserve the English adverbial beta clause meaning in the target texts throughout of translation process by using "Google Translate".

This study uses a qualitative descriptive method. The selected date is collected from the English novel, "The Old Man and the Sea" which is written by American writer, Hemingway and its translation in Arabic translation by "Google Translate". The study adopted Halliday's theory of functional grammar and Newmark's theory of semantic and communicative translation as a model for analyzing the selected data.

The findings revealed that there are some deviations of the English adverbial clause in the translation process, such as adding new elements or removing existing elements from the source text in Google Translate's rendering of the data. These deviations have affected the conveyance of the adverbial beta clause intended meaning in the target text.
\end{abstract}

Keywords: Google translate, adverbial clause, semantic translation, communicative, functional grammar and Old Man and the Sea

\section{Introduction}

This paper is going to investigate the translation of the English adverbial clause in Hemingway's novel The Old Man and the Sea from English into Arabic by using "Google Translate" (GT). The English adverbial clauses (EADCLs) are among grammatical devices which might cause problems in translation of the complex clause when they function as subject, object and complement (Halliday, 2014). Another reason may cause a problem also is the structure of the EADCLs. Furthermore, the EADCLs, because of its dependent nature often poses problems. The present study suggested a theory to test the selected data which may solve these problems. The theory is Newmark's theory of semantic and communicative translation in Arabic translation.

Accordingly, the importance of this research is showing some methods for translating the English adverbial clause from English into Arabic language, due to differences between languages which may cause some problems in the process of translating by using GT in order to achieve the purpose of the study.

The present study deals with analysing of the GT's translation throughout analysis of the translation of the selected English texts into Arabic to answer the research questions which are:

1) How the English adverbial beta clause functions are rendered into the Arabic texts by using "Google Translate".

2) How is to preserve the English adverbial beta clause meaning in the target texts throughout of translation process by using "Google Translate".

As a result, the current study is an attempt to contribute by making a better translation by using GT. In other words, it will contribute to avoiding the same error of translation in translating the English adverbial clause which might happen in the future. 


\section{Literature Review}

\subsection{Google Translate}

Google Translate (GT) is considered the most popular and important machine translation that is used to translate from one language into another by the most people around the world. Thus, this research tries to describe the translation errors found in the translation process of GT in translating the selected literary texts from English into Arabic, and the quality of the translation product in the target language.

In other words, GT has been used to help people in translating words, phrases, clauses, or paragraphs from the so the SL into the TL. Kroulek indicates that more than 500 million people use GT, around the world. In addition, it is used to translate more than 100 billion words per day to support 107 languages. Consequently, the translation quality of the GT is very important for the most people around the world because that GT translates text, speech, and text images within. Precisely, GT functions to translate a whole web page to select languages, a document uploaded by the users to selected languages, translate spoken language into the TL.

Likewise, it makes instant translation accessible inside any app without exiting or switching it. Equally, it recognizes text in a picture taken by the users and it can translate the text on the screen immediately by images. Similarly, it can render language that is handwritten on the phone screen or drawn on a virtual keyboard without the support of a keyboard. Correspondingly, it translates written words or text in a foreign language which is related to the present study. GT provides the pronunciation, dictionary, and listening to the translation. Therefore, GT plays a significant role in translating the text from English into Arabic. If GT's translation is inaccurate in the TL that will give effect on the understanding of the SL text.

\subsection{Newmark's Theory of Semantic and Communicative}

The theory is Newmark's theory of semantic and communicative translation in Arabic translation. Peter Newmark is one of the most outstanding translation theorists in contemporary Britain. Over the years, he has been engaged in research work of translation theory and practice. Newmark (1988, p. 5) defines a translation as "rendering the meaning of a text into another language in the way that the author intended the text". He has put forward his own opinions on many translation theories (Wei, 2015; Liu, 2017). Newmark, the main concern of translation theory is to determine appropriate translation methods for the widest possible range of texts or text-categories and to provide a framework of principles for translating texts and criticizing translation.

One of these theories is Newmark's theory of semantic and communicative translations which is considered a great contribution to the field of translation study in the world (Newmark, 1988). According to Newmark, the conflict of loyalties, the gap between emphasis on the source and target language will always remain as the overriding problem in translation theory and practice. However, the gap could perhaps be narrowed by using communicative and semantic translation (Liu, 2017).

Fundamentally, both semantic and communicative translation complies with the usually accepted syntactic equivalents and equivalent - effect is secured for the two languages. Only semantic and communicative translations fulfil the two main aims of translation, which are first accurate, and second economy. There is no one communicative nor one semantic method of translating a text- there are in fact widely overlapping bands of methods. A translation can be more, or less, semantic - more or less communicative - even a particular section or sentence can be treated more communicatively or less semantically (Newmark, 1981, p. 40).

This theory will be used as tools for describing and analyzing semantically to preserve the adverbial clause structure in Arabic translation. In the respect to the present study, Newmark (1988) indicates that translators have to preserve the intended meaning of the source text in the target text. In other words, the translator's task is to extract from the source text its intended meaning, using concepts of grammar and semantics. These structural effects on the intended meaning may lead to confusion among the target readers, particularly, in terms of grasping the intended meanings of the English literary text "The Old Man and the Sea".

\subsection{The English Adverbial Clause}

The term of complex sentences defined differently by different scholars, in traditional grammar, a complex sentence is defined a sentence that contains an independent clause and at least one dependent clause joined with an appropriate conjunction or pronoun. Musser, (2008, p. 4) defined a Complex Sentence, that consists of one independent clause and one or more dependent clauses. Therefore, we can classify CLs functionally into Nominal clause (NCL) and ADBCL. An Adverbial Dependent Clause (ADBCL) is a dependent clause which acts as an adverb part of another clause (Alexander, 1988, p. 24). This clause functions mainly as adjuncts and disjuncts (Quirk et al., 1991, p. 26). It describes the action of the main clause as well as providing information on how, where, when, and why the action or event took place, such as the following example. 
(1). /// When we come // we shall visit your home ///
A $\quad S \quad P$
$\mathrm{S} \quad \mathrm{P}$
A

In other words, an ADBCL is a dependent clause which acts as an adverb part of another clause (Alexander, 1988, p. 24). ADBCL function mainly is as adjuncts and disjuncts (Quirk et al., 1991, p. 26). It describes the action of the main clause. Adverbials function to provide information on how, where, when, and why the action or event took place. Besides, they can be classified as follows:

\section{a. Adverbial $\beta$ Clauses of Time:}

An ADBCL of time may be introduced by such subordinates as: after, before, when, as, as soon as, until, and others, e.g.

$$
\beta \quad \alpha
$$

(2) Before he left, he said goodbye to his friends.

$\alpha \quad \beta$

(3) She came back when the night fell.

b. Adverbial $\beta$ Clauses of place:

$\mathrm{ADBCL}$ of clauses are usually introduced by where and wherever, e.g.

$\beta$

$\alpha$

(4) We stopped where the river became wider.

c. Adverbial $\beta$ Clauses of Condition:

This kind of ADBCL may be introduced by if, unless, provided that, so long as, etc. The different types of conditional clauses are distinguished by the form and meaning of conditional clauses as the following:

\section{Open conditional clauses:}

This type of conditional clauses may contain a condition that may or may not be fulfilled, e.g.

$\beta$

$$
\alpha
$$

(5) If he is around, John will do it.

\section{> Hypothetical Conditional Clauses:}

This type of a conditional clause makes a hypothesis which may be contrary to a fact, or it may imply a doubt, e.g.

$\beta \quad \alpha$

(6) If he drove fast, he would arrive early.

\section{Alternative Conditional Clauses:}

An alternative conditional clause is introduced by the correlative (whether ... or). It is used to give a choice between two possible conditions, e.g.

$$
\beta \quad \alpha
$$

(7) Whether he will come or not, I will leave.

\section{$>$ Universal Conditional Clauses:}

A universal conditional clause may be introduced by one of the wh- compound words such as whatever, whoever, however, etc. It indicates a free choice from any number of conditions, e.g.

$\beta$

$\alpha$

(8) Whatever he says, people believe him.

\section{d. Adverbial $\beta$ Clauses of Concession:}

An ADBCL of concession can be subordinated to the main clause to imply a contrast between the two circumstances. It can be introduced by: though, although, even, if, etc., e.g.

$\beta$$$
\alpha
$$

(9) Though he tried hard, he was not successful. 
$\beta$

$\alpha$

(10) Although tired, he climbed the mountain.

e. Adverbial $\beta$ Clauses of reason:

$\mathrm{ADBCL}$ of reason can be introduced by because, since, as, etc., e.g.

(11) As I did not find him, I went back home.

\section{f. Adverbial $\beta$ Clauses of Purpose:}

ADBCL of purpose can be introduced by so that, in order that, so as, etc., e.g.

$\alpha \quad \beta$

(12) He left early so as to catch the train.

g. Adverbial $\beta$ Clauses of Result:

ADBCL of result can be introduced by so... that, such... that, so, as, etc., e.g.

$\alpha$

$\beta$

(13) He was so polite that everyone liked him.

h. Adverbial $\beta$ Clauses of Manner and Comparison:

$\mathrm{ADBCL}$ of manner and comparison indicate the sequential manner and educational or differentiating comparison between the main clause and the subordinate clause. They can be introduced by: as...as, too... to, more, as if, etc., e.g.

$\alpha \quad \beta$

(14) They treated us as if we were strangers.

i. Adverbial $\beta$ Clauses of Proportion:

This type of ADBCL can be introduced by the...the..., as... to express a proportionality or equivalence of tendency or degree between the two circumstances.

$\beta \quad \alpha$

(15) The nearer I got to the house, the more agitated I grew.

j. Adverbial $\beta$ Clauses of Preference:

$\mathrm{ADBCL}$ of preference can be introduced by: rather than, sooner than, e.g.

$\beta$

$\alpha$

(16) Rather than going to work, he chose to stay at home.

The Method section describes in detail how the study was conducted, including conceptual and operational definitions of the variables used in the study, Different types of studies will rely on different methodologies; however, a complete description of the methods used enables the reader to evaluate the appropriateness of your methods and the reliability and the validity of your results, It also permits experienced investigators to replicate the study, If your manuscript is an update of an ongoing or earlier study and the method has been published in detail elsewhere, you may refer the reader to that source and simply give a brief synopsis of the method in this section.

\section{Method}

\subsection{Research Approach}

The current study employed a descriptive qualitative approach which concerned with textual analysis. Basically, the qualitative approach aims at proposing an appropriate model for this study which emphasis on the English adverbial beta clause functions which they are rendered into the Arabic texts by using "Google Translate. Specifically, the descriptive qualitative approach is used to describe and delineate the phenomenon of translation of the English adverbial beta clause functions naturally without the intervention of an experiment or an artificially contrived treatment. In this study, the descriptive research is used as a method in which the researcher uses the technique of seeking, collecting, classifying and analysing the data to solve the problems pertaining to The Old Man and the Sea and its translation in Arabic by using Google translate. More specifically, the qualitative approach is considered suitable for the analysis of the collected data which are the core unit of analysis in the present study. The data comprised a total of 24 English adverbial beta clause and their translated 
counterparts in Arabic by using GT. However, this paper analyses only 8 such examples, which fall under the categories of the adverbial beta clause.

\subsection{Data Collection Procedure}

The study sheds light on the translation of the English adverbial clauses in process of translation from English into Arabic. The date extracted from Hemingway's novel The Old Man and the Sea, and its Arabic translation by using GT. So first of all adverbial beta clauses in both languages were outlined. Then, the English adverbial clause was analyzed in both languages. The next step was to compare and contrast the Arabic translation with their original texts The Old Man and the Sea, by Ernest Hemingway, translated by using GT.

In this study, collecting the data required the researcher to read the The Old Man and the Sea in its original language as the first step to sort out the examples that have an English adverbial clause. Second, the sorted-out examples were classified according to their functions into three main topics that constitute the interest of this study, namely the English adverbial clause functions as subject, the English adverbial clause as object and the English adverbial clause as complement. Then, the target versions of these issues are spotted out from the selected translations. In short, data collection includes three steps: the first involved identifying the examples of each type of the English adverbial clause; secondly, classifying them into the main issues related to the English adverbial clause structure, and finally, outlining the Arabic translations of the English adverbial clause in The Old Man and the Sea.

\subsection{Data Analysis}

The data are analyzed according to the following steps:

To determine the function and meaning of the English adverbial clause in Hemingway's The Old Man and the Sea. First step, the selected ST examples were copied from the source text and pasted in the GT text for translation. Second, the selected texts were translated into the TL texts. Third step, through comparing and contrasting the structure and meaning they convey with the ST intended meanings determined to find out whether the selected translator adopted semantic and communicative translation, were critically analyzed in terms of whether they provide the functional equivalence to the ST examples or not. The fourth step, the TTs was further analyzed according to Halliday's functional grammar (1994) to assess renderings of the ST meanings intended.

Fifth step, the STs and the TTs were analyzed via comparing them with each other to identify the points of similarities and differences. This methodology is adopted for it is more applicable to the analysis of the translations of an English adverbial clause in the data examined. In other words, the model employed provides the translator with more freedom to opt for the more communicative rendering when it comes to dealing with the unconventionally implied meanings. Finally, the English equivalents used in the TT were also examined in terms whether they have approximate or similar meaning and structure of the ST or not for every sample was used in the translations investigated, was identified fully in comparison with the original.

\section{Results and Discussions}

In this section, the written Arabic translation of the adverbial beta clause by using GT was assessed through comparative analysis with the ST The Old Man and the Sea. The analysis revealed that the ST samples with the English adverbial clause were translated differently into the TT. In this case, specifically, the English adverbial clause has been rendered into different structures such as group, alpha clause, $\beta C L$ but having different functions and complex clause.

The meaning of the CCL in Hemingway's "The Old Man and the Sea" has been examined in terms of Newmark's theory of semantic and communicative translation. The emphasis here is that the intended meaning of the ST should be rendered to the TT without adding or taking out information that may change the ST meaning in the TT. In short, the CCL intended meaning has been identified by using Halliday's (1994) introduction to Functional Grammar combined with Newmark's theory of semantic and communicative translation (1988). Accordingly, the analysis of the data focused on comparing 8 of the complex clauses in the ST with their counterparts in the Arabic translations to find out some of the deviations of the CCLS in the translation process that the translator might have done semantically and syntactically. Such deviations in the AD $\beta C L S$ have not achieved the translation equivalence between the two texts, whereby rendering the ST into the TT, such as translating the $\mathrm{AD} \beta C \mathrm{C}$ into group, clause or complex clause could have resulted in the change of the intended meaning of the ST in the TT.

Translating adverbial clause structure 


\section{1) Adverbial beta clause of time:}

(1) ST: when the fishermen thought they were at a hundred. (P: 18, L: 17).

TT: عندما اعتقد الصيادون أنهم في المائة

In example1, the adverbial beta clause of time when the fishermen thought they were at a hundred in the ST has been translated into a nominal that clause عندما اعتقد الصيادون أنهم في المائة in the TT. In this case, new information which are not found in the ST have also been added in the TT. Here, the adverbial beta clause of time has been translated into the nominal that clause by the rendering they were at a hundred in the ST into in the TT. Thus, GT has failed to reproduce the adverbial beta clause of time equivalence between the two selected texts. In Arabic, the $\beta$ clause they were at a hundred in the ST which could be rendered into achieve translation equivalence during the rendering process of the ST, as well as its intended meaning.

\section{2) The English adverbial clause of Place:}

(2) ST: He reached the point where it would break. (P: 23, L: 14)

\section{TT: وصل إلى النقطة التي سينكسر فيها}

In example 2, the adverbial $\beta$ clause of place where it would break which contains where in the ST has been translated into the relative clause التي سينكسر فيها in the selected Arabic translation. Thus, in this example, there is a difference in the structure between the ST and TT because where in the ST has been translated into التئit) whose meaning is different where in the selected English text. So, the structural equivalence could be achieved introduced by translating where in English into حيث (haith) in Arabic throughout the translation process. Thus, the English clause where it would break could be rendered into حيث سينقطع بها. The suggested translation of the ST is in the TT.

\section{3) The English adverbial clause of concession:}

(3) ST: He knew what a huge fish this was. (P: 16, L: 21).

TT: كان بعرف ما هي سمكة ضخمة هذه

In example 3, the adverbial $\beta$ clause of concession what a huge fish this was has been translated into the nominal wh-clause in the TT ما هي سمكة ضخمة هذه . In this case, the adverbial $\beta$ clause of concession in the ST has been translated into the different structure in the TT. This has caused the adverbial $\beta$ clause of concession and its translation to be equivalent semantically and syntactically. In this regard, the translation equivalence could be achieved by rendering the SL text into اي سككة ضخمة هذه in the TT.

4) The English adverbial clause of condition: (P: $22, L: 36)$

(4) ST: If there is a hurricane you always see the signs of it in the sky for heads. (P: 52, L: 10)

TT: إذا كان هناك إعصار فدائماً ما ترى علاماته في السماء

In example 4, the adverbial $\beta$ clause of concession If there is a hurricane in the ST with present tense has been translated into adverbial $\beta$ clause of time clause in the TT in the past tense إذا كان هناك إعصار فدائماً. Thus, the translation has failed to reproduce the $\beta C L$ equivalence between the two selected texts. To achieve translation equivalence between the adverbial $\beta$ clause of concession and its translation in Arabic, it is needed to introduce if by (idha) with present tense which is when and similar to if in English, in addition to the translation of the rest text also it is needed to render سترى علاماته في السماء its equivalence in Arabic.

\section{5) The English adverbial clause of purpose:}

(5) ST: He was feeling better since the water and he knew (P: 35, L: 25).

TT: كان يشعر بتحسن منذ الماء وكان يعلم

In example 6, the ADBCL of purpose since he kept well within his speed in the ST has been translated into the nominal that clause نادأم أنه بقي في نطأق سرعته ADBCL of purpose in the ST and the nominal that clause in the TT are different structurally and the translation has not reproduced the ADBCL of purpose equivalence between the two selected text in this example. To achieve the ADBCL of purpose equivalence between the ST and its translation in the TT, the ADBCL of purpose in Arabic must be introduced by $\mathrm{i}$ (mundhu).

6) The English adverbial clause of result:

(6) ST: He had stayed so close that the old man was afraid he would cut the line with his trail (P: 18, L: 3). القد ظل قرييًا جدًا لدرجة أن الرجل العجوز كان يخشى أن يقطع الخط:TT 
In example 6, the ADBCL of result that the old man was afraid in the ST has been translated into the nominal

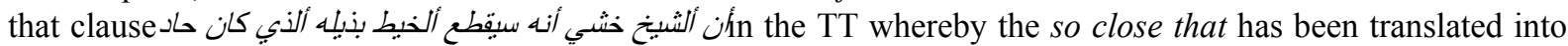
قريبأ لارجة أن Here, the ADBCL of result and the nominal that clause is different structurally. Thus, in this case, the translation has not reproduced the ADBCL of result equivalence between the two selected texts. In this regard, the ADBCL of result equivalence could be achieved by translating 'so close that' in the ST into لذ in the TT when rendering from English into Arabic.

\section{7) The English adverbial clause of reason:}

(7) ST: He did not like to look at the fish anymore since he had been mutilated. (P:29, L:7)

TT: لم يعد يحب النظر إلى السمكة بعد أن تعرض للتشويه

In example 7, the adverbial $\beta$ clause of reason, since he had been mutilated in the ST has been translated into the Adverbial beta clause of time بعد أن شوهت in the TT whereby 'since' has been translated into بعد أن. Here, the translation has not reproduced the adverbial $\beta$ clause of reason in the ST into its equivalence in the TT. Likewise, the structural differences of the ST have led to a change of the ST intended meaning in the TT. In this case, achieving translation equivalence could be achieved if the ADBCL of reason is introduced by لأن أو بسبب (bisabab or liann) in Arabic, which is similar to 'since' in English.

\section{8) The English adverbial clause of proportion:}

(8) ST: He saw the phosphorescence of the Gulf weed in the water as he rowed over the part of the ocean (P: 9, L: 15).

TT: رأى فسفورة حشائش الخليج في الماء وهو يجدف فوق جزء من المحيط

In example 8, the adverbial $\beta$ clause of proportion as he rowed over the part of the ocean in the ST has been translated into the compound sentence وهو يجف فوق جزء من الدحيط TT. Thus, here, the adverbial $\beta$ clause of proportion in the ST has been translated into the complex clause in the TT and are different structurally. This structural difference is likely to have effects on the function of the rendered adverbial $\beta$ clause of proportion in the TT. However, the translation equivalence could be achieved by using by حالما (Halama) in rendering the adverbial $\beta$ clause of the proportion of the ST into Arabic, as it is similar to as in English.

\section{Conclusion}

In the light of the above discussion on the analysed data of the adverbial beta clause, it can be stated that the process of GT's translation still needs some improvements in translating the adverbial beta clause which is related to there are some deviations of the adverbial beta clause in the translation process, such as adding new elements or removing existing elements of the English adverbial clause in into Arabic which have led to the changes of the functions which leads affected the intended meaning in the TT. partially or completely.

Consequently, this study attempts to give input as a contribution to make a better translation of the English adverbial beta clause function by using GT, in order to preserve the ST intended meaning of the English adverbial beta clause when rendering the ST into the TT during the translation process.

\section{References}

Aziz, Y. (1989). A Contrastive Grammar of English and Arabic. University of Mosul.

Baker, M. (1992). In other words: A coursebook on translation. London \& New York: Routledge.

Baker, M. (2011). In other words: A coursebook on translation. London \& New York: Routledge. https://doi.org/10.4324/9780203832929

Berry, H. M. (1975). An introduction to systemic linguistics: Structure and systems (Vol. 1). BT Batsford Limited.

Halliday, M. A. K. (1961). Categories of the theory of grammar. Word, 17(3), 241-292. https://doi.org/10.1080/00437956.1961.11659756

Halliday, M. A. K. (1994a). Functional grammar. London: Edward Arnold.

Halliday, M. A. K. (1994b). An Introduction to Functional Grammar (2nd ed.). London: Edward Arnold.

Halliday, M. A. K. (2014). An introduction to functional grammar (revised by Christian MIM Matthiessen). London, New York: Arnold.

Halliday, M. A. K., \& Matthiessen, M. I. M. (2014). Halliday's Introduction to Functional Grammar (4th ed.). London: Routledge. https://doi.org/10.4324/9780203783771 
House, J. (1997). Translation quality assessment: A model revisited (Vol. 410). Gunter Narr Verlag.

Jakobson. (1959). On Linguistic Aspects of Translation. In R. Brower (Ed.), On Translation. Cambridge, M.A.: Harvard University Press.

Liu, F. L. (2017). A Comparative Study of Nida and Newmark's Translation Theories. International Journal of Liberal Arts and Social Science, 5(8).

Jones, P. W., Quirk, F. H., \& Baveystock, C. M. (1991). The St George's respiratory questionnaire. Respiratory Medicine, 85, 25-31. https://doi.org/10.1016/S0954-6111(06)80166-6

Manfredi, M. (2008). Translating Text and Context: Translation Studies and Systemic Functional Linguistics (Vol. 1, Translation Theory, Quaderni del CeSLiC, Functional Grammar Studies for Non-Native Speakers of English, series ed. 1D.R. Miller). Bologna, Dupress

Martin, J. R., Matthiensen, C. M. I. M., \& Painter, C. (1997). Working with Functional Grammar. London: Arnold.

Martín, R. M. (2000, December). Translation Strategies. In Investigating Translation: Selected Papers from the 4th International Congress on Translation (Vol. 32, p. 129). Barcelona, 1998. John Benjamins Publishing. https://doi.org/10.1075/btl.32.16mun

Muir, J. (1972). A modern approach to English grammar: An introduction to systemic grammar. London: Batsford.

Munday, J. (2016). Introducing translation studies: Theories and applications. London \& New York: Routledge. https://doi.org/10.4324/9781315691862

Newmark, P. (1987). The use of systemic linguistics in translation analysis and criticism. New York: Prentice Hall. https://doi.org/10.1075/z.lt1.27new

Newmark, P. (1988). Approaches to translation. New York: Prentice Hall.

Nida, E. A., \& Taber, C. (1969). The Theory and Practice of Translation. Leiden: E. J. Brill. https://doi.org/10.2307/411434

Quirk, R., \& Greenbaum, S. (1991). A University Grammar of English. London: Longman.

Russell, J. (January 14, 2015). Google Translate Now Does Real-Time Voice and Sign Translations on Mobile. TechCrunch. AOL. Retrieved May 28, 2017.

Ryan, K. (October 13, 2011). Google Translate conversation mode expands to 14 languages. GigaOM.

Setalvad, A. (July 29, 2015). Google Translate adds 20 new languages to video text translation. The Verge. Vox Media. Retrieved March 23, 2017.

Turovsky, B. (July 29, 2015). See the world in your language with Google Translate. Official Google Blog. Retrieved March 23, 2017.

Velazco, C. (October 13, 2011). Google Translate for Android Gets Upgraded "Conversation Mode". TechCrunch. AOL. Retrieved May 28, 2017.

Wang, M. (2014). A study on semantic and communicative translation of magical things in Harry Potter. Studies in Literature and Language, 8(2), 26.

Wei, L. (2015). Translation of Films under Newmark's Translation Theory. https://doi.org/10.2991/icemet-15.2015.102

\section{Copyrights}

Copyright for this article is retained by the author, with first publication rights granted to the journal.

This is an open-access article distributed under the terms and conditions of the Creative Commons Attribution license (http://creativecommons.org/licenses/by/4.0/). 